\title{
Stability Analysis of Mathematical Model on HIV Infection with the Effects of Antiretroviral Therapy
}

\section{Analisis Kestabilan Model Matematika Infeksi Penyakit HIV dengan Pengaruh Terapi Antiretroviral}

\author{
Lilis Dwi Sapta Aprilyani*1), Kasbawati $^{* 2)}$, Syamsuddin Toaha ${ }^{* 3)}$
}

\begin{abstract}
HIV is a retrovirus, a virus which has enzymes and can convert genetic material from RNA to DNA. Antiretroviral therapies are the treatment to make the activity of the virus slow. The purpose of this article is to develop a mathematical model of HIV infection by reviewing antiretroviral therapy, analyze the equilibrium point, and determine the effectiveness of antiretroviral therapy. There are two equilibrium points in this HIV infection model, namely infection-free equilibrium and infected equilibrium. Numerical simulations are carried out based on selected parameters showed that infection free equilibrium is reached when the effectiveness of antiretroviral therapy is 0,4 for RT inhibitor and 0,3 for Protease Inhibitor. This means that antiretroviral therapy may change infected conditions to infection free conditions.
\end{abstract}

Keywords: HIV infection, stability analysis, antiretroviral therapy

\begin{abstract}
Abstrak
HIV termasuk kelompok retrovirus yaitu virus yang mempunyai enzim dan dapat mengubah materi genetik RNA menjadi DNA. Terapi antiretroviral dilakukan sebagai upaya memperlambat aktivitas virus. Tujuan dari artikel ini yaitu mengembangkan model matematika dari infeksi HIV dengan meninjau terapi antiretroviral, menganalisis titik kesetimbangan, dan menentukan efektifitas terapi antiretroviral. Pada model infeksi HIV yang telah dikembangkan diperoleh dua titik kesetimbangan, yaitu bebas infeksi dan terinfeksi. Simulasi numerik berdasarkan parameter yang telah dipilih menunjukkan bahwa keadaan bebas infeksi dapat dicapai ketika efektivitas terapi ART yang digunakan adalah 0,4 untuk RT inhibitor dan 0,3 untuk Protease inhibitor. Ini berarti bahwa terapi antiretroviral yang tepat dapat mengubah keadaan terinfeksi menjadi bebas infeksi.
\end{abstract}

Kata kunci: Model Infeksi HIV, Analisis kestabilan, Terapi Antiretroviral.

\section{Pendahuluan}

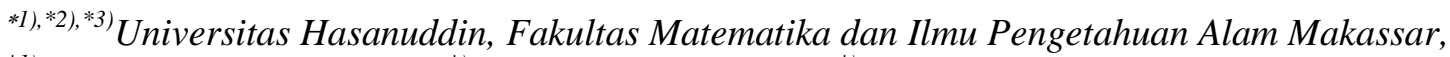

${ }^{* 1)}$ lilisdwisapta@gmail.com, ${ }^{* 1}$ kasbawati@gmail.com, ${ }^{* 1}$ syamsuddint@yahoo.com. 


\section{Lilis Dwi Sapta Aprilyani, Kasbawati, Syamsuddin Toaha}

Human immunodeficiciency virus (HIV) menyebar dengan cepat ke setiap sudut dunia sejak penemuan AIDS pada tahun 1981 yang menyebabkan ancaman serius bagi kesehatan manusia. HIV adalah retrovirus yang menyerang sistem kekebalan tubuh, terutama sel T CD4+. Sel T CD4+ merupakan salah satu jenis sel darah putih yang diproduksi oleh sumsum tulang, yang merupakan pendorong utama respon imun[1]. Secara bersamaan, ketika tubuh manusia terinfeksi HIV, tubuh dapat merangsang produksi Cytotoxic T Lymphocytes $(C T L)$, yang dapat membunuh sel yang terinfeksi HIV. CTL adalah respon imun utama dalam tubuh manusia, oleh karena itu, CTL memainkan peran penting dalam penekanan HIV dengan membunuh sel-T yang terinfeksi virus[4].

Pemodelan matematika dinyatakan sebagai suatu konstruksi matematis untuk memahami suatu fenomena yang terjadi dalam kehidupan kita, salah satunya untuk mengetahui penyebaran infeksi virus HIV. Model dasar infeksi HIV dirumuskan oleh Wodarz dkk pada tahun 2000. Model tersebut menggambarkan interaksi antara populasi virus yang bereplikasi dan tanggapan CTL dengan mempertimbangkan empat variabel, yaitu sel yang tidak terinfeksi $(x)$, sel yang terinfeksi $(y)$, virus $(v)$, dan CTL $(z)$ [6]. Beberapa peneliti matematika yang mengembangkan model infeksi HIV adalah Wodarz., dkk pada tahun 2007 [5], Huang, dkk pada tahun 2015 [3], dan Wang.Y, dkk pada tahun 2017 [4].

Tahapan dalam siklus hidup HIV adalah pengikatan (Binding), peleburan (Fusion), transkripsi balik (Reverse Transcriptease), penggabungan (Integration), replikasi (Replication), perakitan (assembly), lalu terbentuk virus baru yang mengalami maturase dan siap menginfeksi sel-sel lainnya[2]. Terapi antiretroviral (ART) adalah penggunaan obat - obatan HIV untuk mengobati infeksi HIV. Orang yang memakai ART mengambil kombinasi obat HIV dari setidaknya dua kelas obat yang berbeda setiap hari. Karena setiap kelas obat dirancang untuk menargetkan langkah dalam siklus hidup HIV, sehingga ART diangggap efektif untuk mencegah penyebaran virus [2]. Pada penelitian ini, model matematika infeksi pnyakit HIV akan dikembangkan dengan mempertimbangkan pengaruh terapi antiretroviral.

\section{Model Matematika Infeksi HIV}

Misalkan variabel $x$ menyatakan menyatakan jumlah sel CD4 yang tidak terinfeksi, $y$ menyatakan jumlah sel CD4 yang terinfeksi, $v$ menyatakan jumlah virus, dan $z$ menyatakan jumlah CTL. Dinamika dari masing - masing kompartemen dimodelkan berdasarkan asumsi sebagai berikut:

a. Sel CD4 yang tidak terinfeksi diproduksi dalam tubuh dan dapat mati secara alami. Sel CD4 dapat diproduksi oleh proliferasi sel CD4 yang ada. Dengan mengasumsikan proliferasi sel memenuhi fungsi logistik dengan $x_{\max }$ melambangkan kepadatan populasi sel CD4. Infeksi pada sel CD4 terjadi akibat interaksi dengan virus sehingga jumlah sel yang ada akan berkurang.

b. Sel CD4 yang terinfeksi diproduksi karena adanya interaksi antara sel tidak terinfeksi dengan virus. Namun, sel yang terinfeksi dapat berkurang secara alami. Terapi antiretroviral Reverse Transcritase (RT) inhibitor berfungsi untuk menekan produksi sel yang terinfeksi. Sel CD4 merupakan komponen yang mengatur pembentukan respon imun spesifik sehingga memungkinkan virus untuk menyebar melalui pembelahan sel CD4 yang terinfeksi. Adanya respon imun spesifik selular merangsang terbentuknya CTL dalam tubuh sehingga sel yang terinfeksi diuraikan oleh limfosit T sitotoksik (CTL). Dengan mengasumsikan proliferasi sel memenuhi fungsi logistik dengan $y_{\max }$ melambangkan kepadatan populasi sel CD4 yang terinfeksi. 


\section{Lilis Dwi Sapta Aprilyani, Kasbawati, Syamsuddin Toaha}

c. Setiap sel yang terinfeksi secara produktif menghasilkan $N$ partikel virus selama masa hidupnya. Virus yang bereplikasi dapat dihambat dengan terapi antiretroviral yaitu protease inhibitor. Partikel virus tersebut akan meluruh secara alami.

d. Respon CTL yang diaktifkan berbanding lurus dengan jumlah sel yang terinfeksi dan akan meluruh secara alami dalam tubuh.

Berdasarkan asumsi - asumsi tersebut, model matematika dapat disusun dalam bentuk sistem persamaan diferensial sebagai berikut:

$$
\begin{aligned}
& \frac{d x(t)}{d t}=s-d x+r x\left(1-\frac{x}{x_{\max }}\right)-k x v \\
& \frac{d y(t)}{d t}=\left(1-\sigma_{1}\right) k x v-\beta y+r y\left(1-\frac{y}{y_{\max }}\right)-p y z \\
& \frac{d v(t)}{d t}=\left(1-\sigma_{2}\right) N \beta y-a v \\
& \frac{d z(t)}{d t}=c y z-b z
\end{aligned}
$$

\begin{tabular}{|c|c|c|}
\hline Parameter & Interpretasi & Satuan \\
\hline$s$ & laju produksi sel CD4 yang tidak terinfeksi & $\mathrm{sel} / \mathrm{mm}^{3}$ \\
\hline$d$ & Kematian sel CD4 yang tidak terinfeksi & $1 /$ hari \\
\hline$k$ & Laiu infeksi & $\mathrm{mm}^{3} /$ virion \\
\hline & & hari \\
\hline$\beta$ & Laju kematian sel CD4 yang terinfeksi & 1/hari \\
\hline$p$ & Laju penguraian sel CD4 yang terinfeksi oleh CTL & $\mathrm{mm}^{3} /$ hari \\
\hline$N$ & Laju produksi virus pada sel yang terinfeksi & virion/sel \\
\hline$a$ & Laju peluruhan partikel bebas virus & 1/hari \\
\hline$c$ & Laju produksi sel CTL & $\mathrm{mm}^{3} /$ hari \\
\hline$b$ & Laju peluruhan sel CTL & $\mathrm{mm}^{3} /$ hari \\
\hline$r$ & Laju proliferasi sel & 1/hari \\
\hline$x_{\max }$ & Kepadatan populasi sel yang tidak terinfeksi & $\mathrm{sel} / \mathrm{mm}^{3}$ \\
\hline$y_{\max }$ & Kepadatan populasi sel yang tidak terinfeksi & $\mathrm{sel} / \mathrm{mm}^{3}$ \\
\hline$\sigma_{1}$ & Efektifitas pengobatan RT & $0 \leq \sigma_{1}<1$ \\
\hline$\sigma_{2}$ & Efektifitas pengobatan protease & $0 \leq \sigma_{2}<1$ \\
\hline
\end{tabular}

Tabel 1. Keterangan Variabel dan Parameter Model dalam Persamaan (1)

\section{Titik Kesetimbangan}

Titik kesetimbangan merupakan solusi yang diperoleh ketika sistem (1) memenuhi kondisi setimbang dalam artian sistem (1) tidak mengalami perubahan apapun terhadap waktu. Titik kesetimbangan tersebut merupakan solusi dari $\frac{d x(t)}{d t}=\frac{d y(t)}{d t}=\frac{d v(t)}{d t}=\frac{d z(t)}{d t}=0$. Dari model yang dikembangkan diperoleh dua titik kesetimbangan yang dinamakan sebagai titik kesetimbangan bebas infeksi $\left(E_{0}\right)$ dan titik kesetimbangan terinfeksi $\left(E_{1}\right)$. Titik tersebut diberikan sebagai berikut:

a. Titik kesetimbangan bebas infeksi 


\section{Lilis Dwi Sapta Aprilyani, Kasbawati, Syamsuddin Toaha}

$$
\begin{aligned}
E_{0} & =\left(x_{0}, y_{0}, v_{0}, z_{0}\right) \\
& =\left(\frac{x_{\max }}{2 r}\left((r-d)+\sqrt{(r-d)^{2}+4\left(\frac{r s}{x_{\max }}\right)}\right), 0,0,0\right) .
\end{aligned}
$$

b. Titik kesetimbangan terinfeksi

$$
\begin{aligned}
& E_{1}=\left(x_{1}, y_{1}, v_{1}, z_{1}\right), \text { dengan } \\
& x_{1}=\frac{x_{\max }}{2 r}\left(\left(-d+r-\frac{\left(1-\sigma_{2}\right) k N \beta b}{c a}\right)+\sqrt{\left(-d+r-\frac{\left(1-\sigma_{2}\right) k N \beta b}{c a}\right)^{2}+\frac{4 r s}{x_{\max }}}\right), \\
& y_{1}=\frac{b}{c}, \quad v_{1}=\frac{\left(1-\sigma_{2}\right) N \beta b}{c a}, \text { dan } z_{1}=\frac{\left(1-\sigma_{1}\right)\left(1-\sigma_{2}\right) k N \beta}{a p} x_{1}+\frac{(-\beta+r)}{p}-\frac{r b}{c p y_{\max }} .
\end{aligned}
$$

Agar titik $E_{1}$ positif (karena menyatakan jumlah populasi) maka syarat yang harus dipenuhi oleh pada kompartemen $z$ adalah $\frac{\left(1-\sigma_{1}\right)\left(1-\sigma_{2}\right) k N \beta}{a p} x_{1}+\frac{(-\beta+r)}{p}>\frac{r b}{c p y_{\max }}$. Nilai $r$ yang menunjukkan laju proliferasi sel harus lebih besar dari nilai laju kematian sel CD4 yang terinfeksi yang dilambangkan dengan $\beta$.

\section{Bilangan Reproduksi Dasar}

Misalkan $\mathcal{F}_{i}(x)$ adalah laju penambahan infeksi baru pada kompartemen $i$ dan $\mathcal{V}_{i}(x)$ adalah laju perpindahan individu pada kompartemen $i$, maka dari Persamaan (1) diperoleh sebagai berikut:

$$
\mathcal{F}(x)=\left(\begin{array}{c}
\left(1-\sigma_{1}\right) k x v \\
0 \\
0
\end{array}\right), \quad \boldsymbol{v}(x)=\left(\begin{array}{c}
\beta y-r y\left(1-\frac{y}{y_{\max }}\right)+p y z \\
-\left(1-\sigma_{2}\right) N \beta y+a v \\
-c y_{\tau} z_{\tau}+b z
\end{array}\right) .
$$

Dari persamaan diatas diperoleh matriks $F$ dan $V$ sebagai berikut:

$$
F=\frac{\partial \mathcal{F}_{i}\left(E_{0}\right)}{\partial x_{j}}=\left(\begin{array}{ccc}
0 & \left(1-\sigma_{1}\right) k x_{0} & 0 \\
0 & 0 & 0 \\
0 & 0 & 0
\end{array}\right) \quad V=\frac{\partial \mathcal{V}_{i}\left(E_{0}\right)}{\partial x_{j}}=\left(\begin{array}{ccc}
\beta-r & 0 & 0 \\
-\left(1-\sigma_{2}\right) N \beta & a & 0 \\
0 & 0 & b
\end{array}\right) .
$$

Nilai bilangan reproduksi dasar dapat ditentukan melalui matriks generasi, dengan:

$$
F V^{-1}=\left(\begin{array}{ccc}
\frac{\left(1-\sigma_{1}\right)\left(1-\sigma_{2}\right) k N \beta x_{0}}{(\beta-r) a} & \frac{\left(1-\sigma_{1}\right) k x}{a} & 0 \\
0 & 0 & 0 \\
0 & 0 & 0
\end{array}\right)
$$

Selanjutnya, nilai eigen terbesar dari matriks generasi disebut dengan bilangan reproduksi dasar atau dapat dituliskan

$$
\mathcal{R}_{0}=\rho\left(F V^{-1}\right)=\frac{\left(1-\sigma_{1}\right)\left(1-\sigma_{2}\right) k N \beta}{(\beta-r) a}\left(\frac{x_{\max }}{2 r}\left((r-d)+\sqrt{(r-d)^{2}+4\left(\frac{r s}{x_{\max }}\right)}\right)\right) .
$$

Dari nilai $\mathcal{R}_{0}$ yang diperoleh dapat dilihat bahwa efektivitas dari terapi antiretroviral berbanding terbalik dengan nilai $\mathcal{R}_{0}$. Semakin besar efektivitas dari $\sigma_{1}$ dan $\sigma_{2}$, maka semakin kecil nilai $\mathcal{R}_{0}$ yang berarti bahwa kondisi agar sistem terbebas dari infeksi dapat terpenuhi.

\section{Analisis Kestabilan Titik Kesetimbangan}




\section{Lilis Dwi Sapta Aprilyani, Kasbawati, Syamsuddin Toaha}

Pada bagian ini, kestabilan dari solusi kesetimbangan $E_{0}$ dan $E_{1}$ akan dianalisis secara lokal melalui proses linearisasi sistem (1) di sekitar titik kesetimbangan tersebut. Proses linearisasi menghasilkan matriks Jacobi untuk masing - masing titik kesetimbangan.

a. Titik Kesetimbangan Bebas Infeksi $\left(E_{0}\right)$.

Untuk titik kesetimbangan $E_{0}$ hasil linearisasi sistem (1) di sekitar $E_{0}$ menghasilkan matriks $J E_{0}$ yang diberikan sebagai berikut:

$$
J E_{0}=\left[\begin{array}{cccc}
-d+r-\frac{2 r x_{0}}{x_{\max }} & 0 & -k x_{0} & 0 \\
0 & -\beta+r & \left(1-\sigma_{1}\right) k x_{0} & 0 \\
0 & \left(1-\sigma_{2}\right) N \beta & -a & 0 \\
0 & 0 & 0 & -b
\end{array}\right] .
$$

Nilai karakteristik $J E_{0}$ merupakan akar-akar polinomial dari persamaan karakterikstik:

$$
\operatorname{det}\left(J E_{0}-\lambda I\right)=0 \text {. }
$$

$$
\left|\begin{array}{cccc}
-d+r-\frac{2 r x_{0}}{x_{\max }}-\lambda & 0 & -k x_{0} & 0 \\
0 & -\beta+r-\lambda & \left(1-\sigma_{1}\right) k x_{0} & 0 \\
0 & \left(1-\sigma_{2}\right) N \beta & -a-\lambda & 0 \\
0 & 0 & 0 & -b-\lambda
\end{array}\right|=0
$$

Sehingga diperoleh

$$
\begin{aligned}
& (-b-\lambda)\left(-d+r-\frac{2 r x_{0}}{x_{\max }}-\lambda\right)\left[\lambda^{2}+(a+\beta-r) \lambda+a(\beta-r)-\left(1-\sigma_{1}\right)(1-\right. \\
& \left.\left.\sigma_{2}\right) k N \beta x_{0}\right]=0 .
\end{aligned}
$$

Jadi diperoleh nilai eigen sebagai berikut:

$$
\begin{aligned}
\lambda_{1} & =-b, \\
\lambda_{2} & =-d+r-\frac{2 r x_{0}}{x_{\max }}=-\left(\frac{s}{x_{0}}+\frac{r x_{0}}{x_{\max }}\right), \\
\lambda_{3}+\lambda_{4} & =-(a+\beta-r)<0, \text { dengan syarat } a+\beta>r \\
\lambda_{3} \lambda_{4} & =a(\beta-r)-\left(1-\sigma_{1}\right)\left(1-\sigma_{2}\right) k N \beta x_{0}=a(\beta-r)\left[1-\mathcal{R}_{0}\right]>0, \text { dengan } \beta>r .
\end{aligned}
$$

Jika $\mathcal{R}_{0}<1$, maka Persamaan nilai-nilai mempunyai akar-akar negatif. Jika $\mathcal{R}_{0}>1$, maka $\lambda_{3} \lambda_{4}=a(\beta-r)\left[1-\mathcal{R}_{0}\right]<0$ yang mengakibatkan Persamaan (3) mempunyai akar positif.

b. Titik Kesetimbangan Terinfeksi $\left(E_{1}\right)$.

Untuk titik kesetimbangan $E_{1}$ hasil linearisasi sistem (1) di sekitar $E_{0}$ menghasilkan matriks $J E_{0}$ yang diberikan sebagai berikut:

$$
J E_{1}=\left[\begin{array}{cccc}
-G & 0 & -k x_{1} & 0 \\
\left(1-\sigma_{1}\right) k v_{1} & -H & \left(1-\sigma_{1}\right) k x_{1} & -p y_{1} \\
0 & \left(1-\sigma_{2}\right) N \beta & -a & 0 \\
0 & c z_{1} & 0 & -b+c y_{1}
\end{array}\right],
$$

Dengan $G=d-r+\frac{2 r x_{1}}{x_{\max }}+k v_{1}, \quad H=\beta-r+\frac{2 r y_{1}}{y_{\max }}+p z_{1}$.

Nilai karakteristik $J E_{0}$ merupakan akar-akar polinomial dari persamaan karakterikstik:

dengan

$$
\lambda^{4}+B_{1} \lambda^{3}+B_{2} \lambda^{2}+B_{3} \lambda+B_{4}=0
$$

$B_{1}=G+H+a$,

$B_{2}=G(H+a)+H a+b p z_{1}-\left(1-\sigma_{1}\right)\left(1-\sigma_{2}\right) k N \beta x_{1}$,

$B_{3}=G H a+\left(1-\sigma_{1}\right)\left(1-\sigma_{2}\right) k^{2} N \beta x_{1} v_{1}+b p z_{1}(G+a)-G\left(\left(1-\sigma_{2}\right) N \beta\right)\left(\left(1-\sigma_{1}\right) k x_{1}\right)$,

$B_{4}=G b a p z_{1}$. 


\section{Lilis Dwi Sapta Aprilyani, Kasbawati, Syamsuddin Toaha}

Titik $E_{1}$ akan stabil asimtotik lokal jika memenuhi syarat kriteria Routh Hurwitz dengan syarat-syarat yang diberikan sebagai berikut:
1) $H_{1}=\left|B_{1}\right|>0$
$=G+H+a>0$,
2) $H_{2}=\left|\begin{array}{cc}B_{1} & B_{3} \\ 1 & B_{2}\end{array}\right|>0$
$=B_{1} B_{2}>B_{3}$,
3) $H_{3}=\left|\begin{array}{ccc}B_{1} & B_{3} & 0 \\ 1 & B_{2} & B_{4} \\ 0 & B_{1} & B_{3}\end{array}\right|>0$
$=B_{1} B_{2} B_{3}>B_{3}^{2}+B_{1}^{2} B_{4}$.

\section{Simulasi Numerik}

Simulasi numerik sistem merupakan gambaran hasil analitik yang telah diperoleh sebelumnya. Dalam simulasi numerik ini dilakukan analisis pengaruh efektifitas ART. Nilai parameter yang digunakan dalam simulasi ini diasumsikan sedemikian sehingga memenuhi syarat kepositifan titik kesetimbangan dan kriteria Routh Hurwitz, yaitu $s=6 \frac{\mathrm{sel} / \mathrm{mm}^{3}}{\mathrm{hari}}, d=$ $0.009 /$ hari, $k=0.0009 \frac{\mathrm{mm}^{3} / \text { virion }}{\text { hari }}, \beta=1 /$ hari, $p=0.066 \frac{\mathrm{mm}^{3}}{\text { hari }}, N=10 \frac{\text { virion }}{\text { sel }}, a=3 /$ hari, $c=0.09 \frac{\mathrm{mm}^{3}}{\mathrm{hari}}, b=0.15 /$ hari,$r=0.3 /$ hari, $, x_{\max }=500 \frac{\mathrm{sel}}{\mathrm{mm}^{3}}, y_{\max }=1100 \frac{\mathrm{sel}}{\mathrm{mm}^{3}}$. Dalam hal ini akan ditunjukkan bahwa peningkatan atau penurunan nilai efektivitas ART dapat mengubah bilangan reproduksi dasar $\left(\mathcal{R}_{0}\right)$ yang didefinisikan pada Persamaan (2). Terdapat 3 kondisi nilai $\sigma_{1}$ dan $\sigma_{2}$. Simulasi yang pertama ketika tidak dilakukan ART sehingga $\sigma_{1}=\sigma_{2}=0$, dengan nilai $\mathcal{R}_{0}$ yang diperoleh adalah 2.163. Simulasi kedua ketika hanya dilakukan salah satu ART $\sigma_{1}=0$ dan $\sigma_{2}=0.4$, dengan nilai $\mathcal{R}_{0}$ yang diperoleh adalah 1.298. Simulasi ketiga ketika dilakukan kombinasi ART yaitu saat $\sigma_{1}=0.4$ dan $\sigma_{2}=0.3$. dengan nilai $\mathcal{R}_{0}$ yang diperoleh adalah 0.713 .
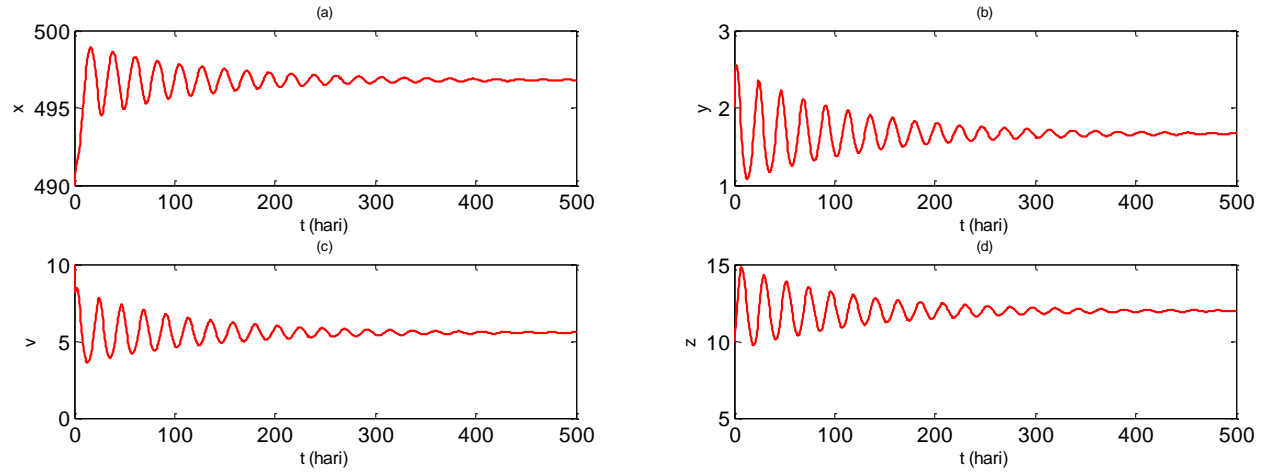

Gambar 1. Perilaku solusi saat $\sigma_{1}=\sigma_{2}=0$.

Berdasarkan Gambar 1 maka virus dan sel terinfeksi masih terdapat dalam tubuh sehingga tubuh memerlukan antiretroviral (ARV) atau bahkan antiretroviral terapi (ART). 


\section{Lilis Dwi Sapta Aprilyani, Kasbawati, Syamsuddin Toaha}
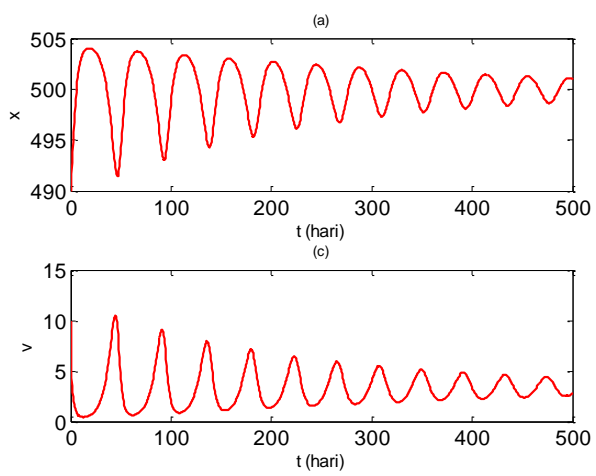
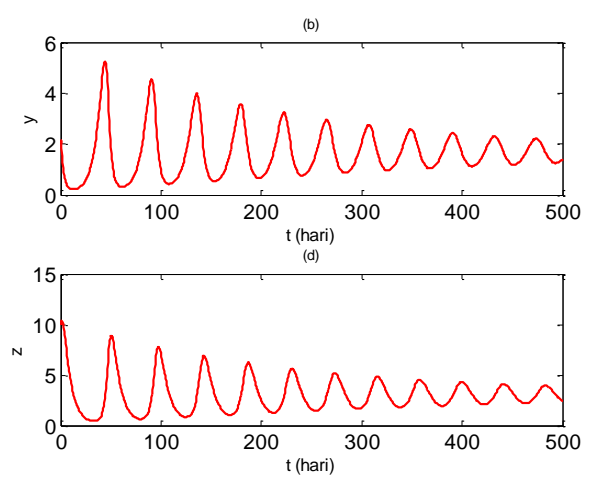

Gambar 2. Perilaku solusi saat $\sigma_{1}=0$ dan $\sigma_{2}=0.4$.

Gambar 2 menunjukkan bahwa dengan antiretroviral (ARV) maka virus dan sel terinfeksi masih terdapat dalam tubuh sehingga tubuh memerlukan antiretroviral terapi (ART).
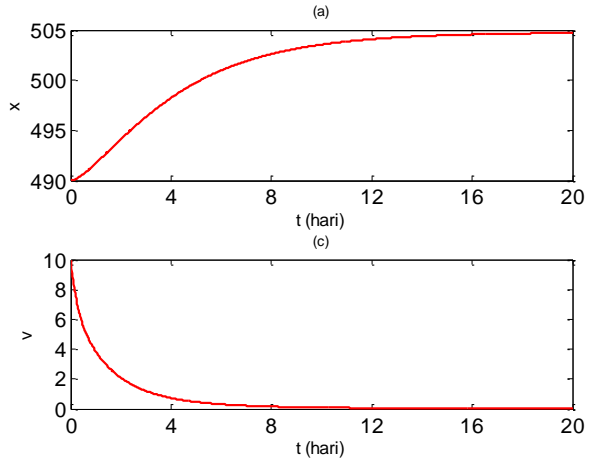

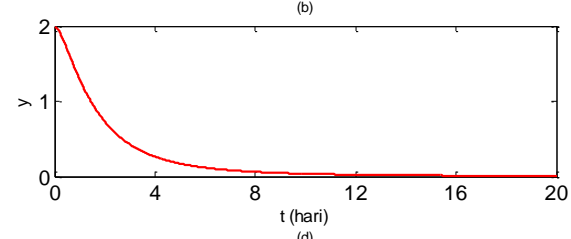

(d)

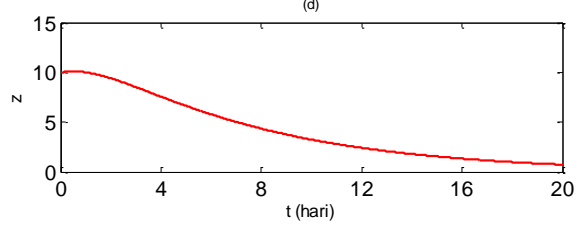

Gambar 3. Perilaku solusi saat $\sigma_{1}=0.4$ dan $\sigma_{2}=0.3$

Gambar 3 menunjukkan bahwa antiretroviral terapi (ART) dengan efektivitas tersebut sehingga menjadi keadaan bebas infeksi.

\section{Kesimpulan}

Pada penelitian ini telah dikembangkan model matematika dari infeksi HIV dengan mempertimbangkan terapi antiretroviral. Berdasarkan parameter yang telah dipilih, akan terjadi kondisi terinfeksi yang memenuhi kriteria Routh-Hurwitz dengan nilai $\mathcal{R}_{0}>1$. Dibutuhkan terapi antiretroviral agar keadaaan terinfeksi menjadi bebas infeksi. Nilai efektivitas dari ART mempengaruhi dinamika dari sistem Persamaan (1) yang menyebabkan nilai $\mathcal{R}_{0}$ besar atau kurang dari 1. Sehingga pada nilai parameter yang dipilih, untuk mencapai keadaan bebas infeksi, nilai efektifitas $\sigma_{1}=0,4$ dan $\sigma_{2}=0,3$.

\section{Daftar Pustaka}

[1] Adak, D., Bairagi, Nandadulal. 2017. Analysis and Computation of Multi-Pathways and Multi-Delays HIV-1 Infection M odel. Journal of Applied Mathematical Modelling, Vol 54, Hal.517 - 536. 
[2] AIDS Info, U.S. Department of Health and Human Services, 2019. Facts sheets about The HIV Life Cycle. Sumber: https://aidsinfo.nih.gov/understanding-hiv-aids/factsheets/19/73/the-hiv-life-cycle, diakses pada tanggal 25 Januari 2020.

[3] Huang, D., Zhang, X., Guo, Y., \& Wang, H. 2015. Analysis of an HIV Infection Model with Treatments and Delayed. Journal of Applied Mathematical Modelling, 1-9.

[4] Wang Yan, Jiang Daqing, Hayar Tasawar., \& Ahmad B. 2017. A stochastic HIV infection model with T-cell proliferation and CTL immune response. Applied Mathematics and Computation, Elsevier, Vol. 315(2017), hal.477-493.

[5] Wodarz, D., \& Hamer, D. H. 2007. Infection Dynamics in HIV-Specific CD4 T cells: Does a CD4 T cell boost benefit the host or the virus?. Journal of Mathematical Biosciences Vol 209: 14-29.

[6] Wodarz, D., \& Krakauer, D. C. 2000. Defining CTL-Induced Pathology: Implications for HIV. Journal of Virology Vol 274: 94-104. 